\title{
Popular Beach Disappears Underwater in Huge Coastal Landslide-Sleeping Bear Dunes, Michigan
}

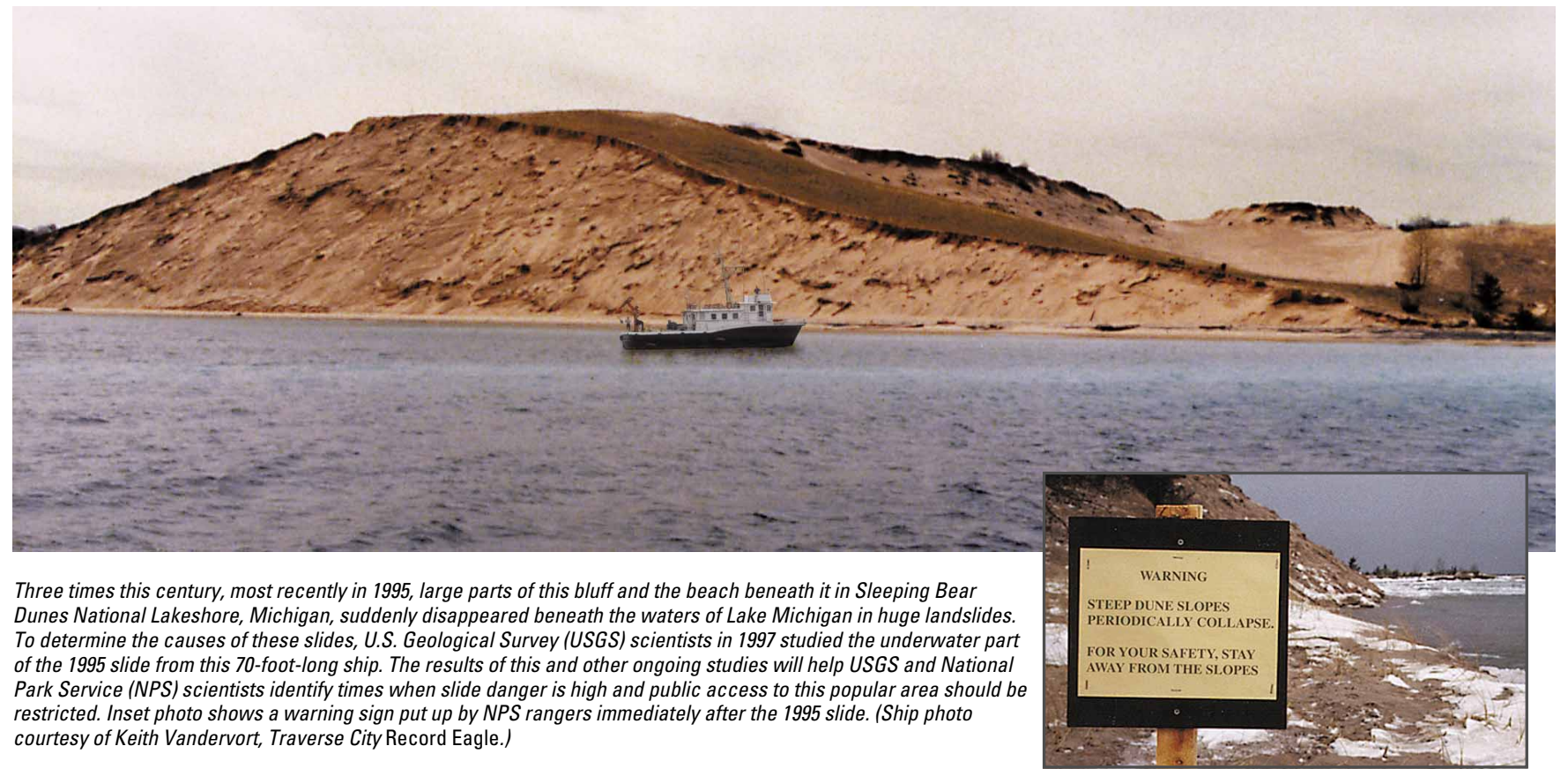

n February 1995, a 1,600-foot
stretch of popular beach at
Sleeping Bear Dunes National
Lakeshore suddenly slid into the
waters of northeastern Lake Michi-
gan. The National Park Service
(NPS) immediately requested the
assistance of the U.S. Geological
Survey (USGS) in evaluating the
hazard at the lakeshore. To protect
the public, USGS and NPS scien-
tists are conducting studies that
will help predict when the land-
slide-prone area will move again.

On an unusually warm February morning in 1995, local resident George Weeks was walking his dog along the shore in Sleeping Bear Dunes National Lakeshore, Michigan. Approaching Sleeping Bear Point, he was shocked to find that where there had only recently been a beautiful beach was now a steep 100-foot drop into Lake Michigan. The millions of cubic feet of sand that made up the beach and part of the high bluff above it had disappeared be- neath the waters of the lake in a huge coastal landslide. Luckily, no one was on this popular beach when it slid.

Alerted by Mr. Weeks to the beach's disappearance, NPS rangers became concerned about the stability of the area and the potential threat to public safety. The rangers immediately posted signs warning park visitors of the possible hazard. They also asked the USGS, which had conducted surveys of the area from 1989 to 1993 as part of a shoreline-change study, to investigate the causes of the slide.

USGS scientists already knew that two previous slides had occurred at Sleeping Bear Point during this century-in December 1914 and March 1971. Because the area

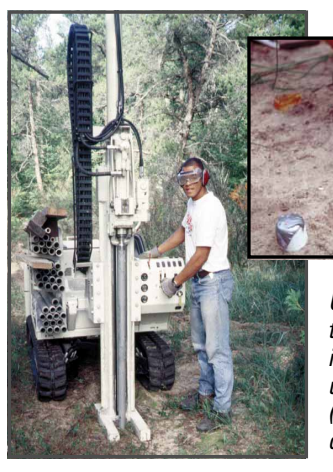

was sparsely populated and access to Sleeping Bear Point was difficult until after the National Lakeshore was dedicated in 1977, little attention was paid to these slides. In 1914, there was a U.S. Life-Saving Service (later part of the U.S. Coast Guard) station near the point to rescue mariners in distress. A boat crew from the station had walked across the 100-foot-high bluff at the point only the day before the bluff's face and about 20 acres of land slumped into Lake Michigan. Fifty-seven years later, in 1971, a similar landslide occurred, and a bathymetric survey of the lake bottom off Sleeping Bear Point conducted shortly afterward by the National Oceanic and Atmospheric Administration (NOAA) found that this slide had left a huge underwater hole.

In their work at Sleeping Bear Point from 1989 to 1993, USGS scientists found that water currents in the area transport sand from southwest to northeast along the shore of Lake Michigan. Once past the point, the currents weaken and deposit sand along the

U.S. Geological Survey (USGS) and National Park Service (NPS) scientists believe that repeated coastal landsliding at Sleeping Bear Point may be related to increases in fluid pressure in the spaces between the grains of sand (pore pressure) that make up the bluff at the point. To test this idea, instruments to measure the pore pressure (piezometers) have been installed within the bluff. Photo shows a USGS scientist drilling a hole for a piezometer (inset). 
More than 35 million cubic feet of sand disappeared beneath the waters of Lake Michigan in a huge coastal landslide at Sleeping Bear Point in 1995. This composite image shows both the onshore and offshore areas removed from the point in that slide. In 1997, U.S.

Geological Survey scientists found a thick blanket of debris from the slide extending more than 2 miles offshore, much farther than expected. Underwater video of the deeper part of the slide showed trees protruding from the sand (inset photo). These trees had been growing on the bluff at Sleeping Bear Point and were swept into deep water with the slide.

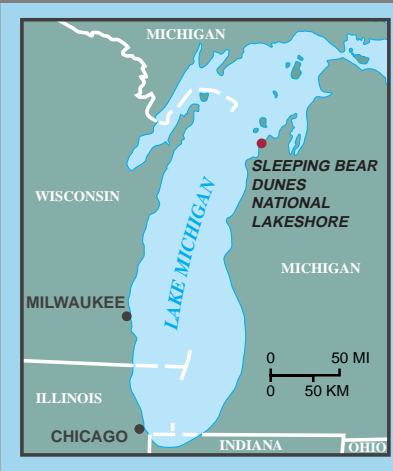

\section{SLEEPING}
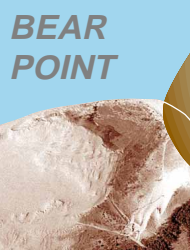

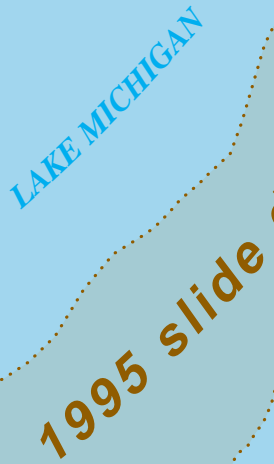

Area removed in landslide Former coastline

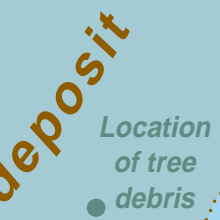
debris

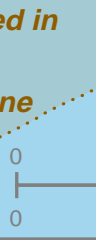

beach and just offshore. By comparing the bottom topography with that charted in 1971 by NOAA, the scientists were able to show that sand was gradually filling the underwater hole from the 1971 landslide at a rate of more than 1.5 million cubic feet per year. Because Sleeping Bear Point is an area where sand is being steadily deposited, the scientists concluded that the coastal landsliding is not the result of erosional undercutting of the offshore slope by water currents.

USGS and NPS scientists now believe that the sliding at Sleeping Bear Point is related to increases in fluid pressure in the spaces between the grains of sand (pore pressure) within the bluff. High pore pressure lessens the forces holding the sand grains together, which may weaken the bluff enough to trigger a slide. The pore pressure may be increased by water from snowmelt in winter being trapped behind the frozen bluff face or within confined sand layers beneath the bluff. This idea is supported by the fact that all three known slides at Sleeping Bear Point happened in unseasonably warm weather during winter months.

To gather the data required to test this and other ideas about how landslides are caused at Sleeping Bear Point, USGS scientists have installed instruments that monitor pore pressure within the bluff and are also using information from Global Positioning System (GPS) satellites to detect any movement that might indicate instability. In 1997, USGS scientists conducted a variety of studies of the underwater part of the 1995 slide from a small ship. Near the shore they found a deep hole where there had been a gently sloping lake bottom. They also found that a thick blanket of debris from the slide extended more than 2 miles offshore into water depths greater than 250 feet, much farther and deeper than expected. Underwater video of the deeper part of the slide showed trees protruding from the sand.

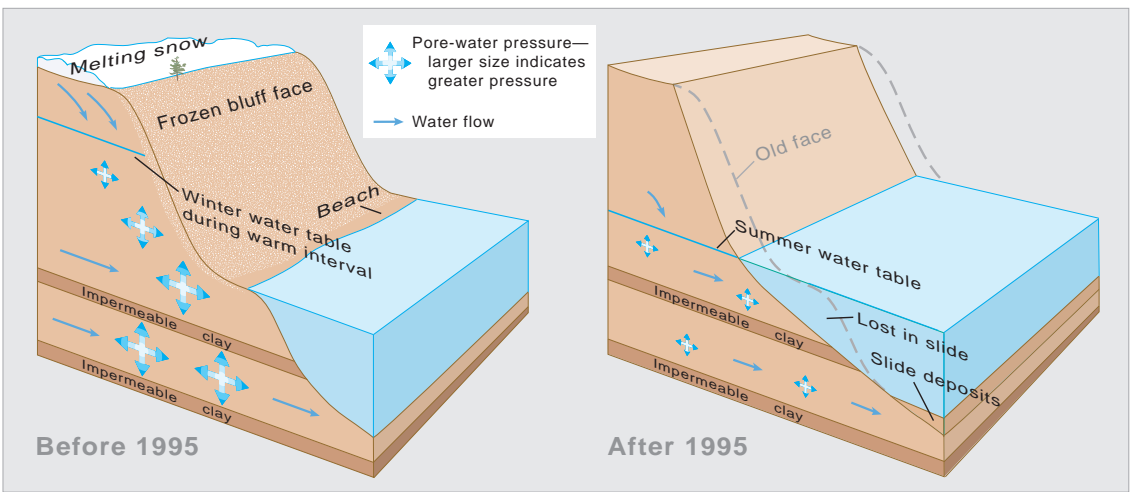

Coastal landsliding at Sleeping Bear Point may be related to increases in fluid pressure in the spaces between grains of sand (pore pressure). High pore pressure lessens the forces holding sand grains together, which may weaken the bluff at Sleeping Bear Point enough to trigger a slide. Pore pressure may be increased by water from snowmelt in winter being trapped behind the frozen bluff face or within sand layers confined by impermeable clay beneath the bluff. This idea is supported by the fact that all three known slides at Sleeping Bear Point $(1914,1971,1995)$ happened in unseasonably warm weather during winter months.

These trees had been growing on the bluff at Sleeping Bear Point and had been swept into deep water with the slide.

The results of these studies will help USGS and NPS scientists identify times when the slide danger at Sleeping Bear Point is high and access should be restricted. The information from the studies will also be used to educate and warn the public about the hazard at the point. Eventually, most monitoring functions will be transferred to the NPS, so that rangers can detect and quickly respond to any increase in the slide hazard. In addition, USGS biologists are conducting studies of the ongoing effects of the slide on fish and other aquatic life in the National Lakeshore.

The cooperative efforts of USGS scientists and the NPS at Sleeping Bear Dunes National Lakeshore not only are advancing understanding of coastal and underwater landslides in the Great Lakes region but also are providing new insights into how such landslides occur in other coastal areas. The work of these USGS scientists is only part of the USGS Coastal and Marine Geology Program's ongoing efforts to protect people's lives and property from geologic and environmental hazards in the coastal zones of the United States.

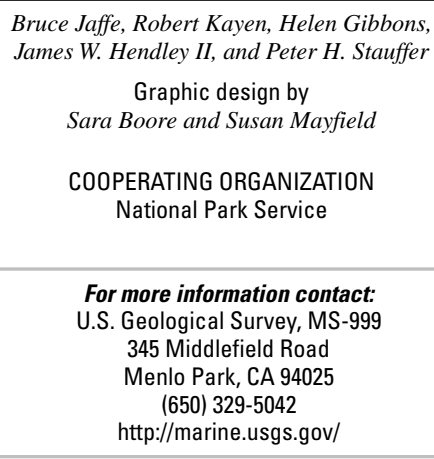

For more information contact:

U.S. Geological Survey, MS-999 345 Middlefield Road Menlo Park, CA 94025 (650) 329-5042 http://marine.usgs.gov/ 